\title{
THE ABACUS IN THE INQUIRE- BASED LEARNING OF ADDITION AND SUBTRACTION
}

\section{OLAVO LEOPOLDINO DA SILVA FILHO}

Universidade de Brasília (UnB). Doutor em Física. Professor no Instituto de Física da Universidade de Brasília, vinculado ao Programa de Pós-Graduação em Ensino de Física.

Brasil. ORCID: http://orcid.org/0000-0001-8078-3065. E-mail: olavolsf@unb.br

\section{MARCELLO FERREIRA}

Universidade de Brasília (UnB). Doutor em Educação em Ciências. Professor no Instituto de Física da Unidversidade de Brasília, vinculado ao Programa de Pós-Graduação em Ensino de

Física. Brasil. ORCID: http://orcid.org/0000-0003-4945-31. E-mail: marcellof@unb.br

\section{DANIELLE XÁBREGAS PAMPLONA NOGUEIRA}

Universidade de Brasília (UnB). Doutora em Educação. Professora no Departamento de Planejamento e Administração da Faculdade de Educação. ORCID: http://orcid.org/0000-00018500-04. E-mail: danielle.pamplona@gmail.com 


\section{THE ABACUS IN THE INQUIRE-BASED LEARNING OF ADDITION AND SUBTRACTION}

This paper adopts the Inquire Based Learning (IBL) as an Teaching technology in the framework of an Educational Theory consisting in a blending of Ausubel's Meaningful Theory and Mathew Lipman's Philosophy for Children Program. The abacus was used to teach addition and subtraction in a meaningful way. The underlying didactic sequence was applied to a private school in the city of Brasilia -DF, to third year primary school students. The didactic sequence successfully helped the students to make the transition from a concrete model to a rather abstract one. We conclude that the didactic sequence helps showing that the integration of the Meaningful Learning (Ausubel) and Lipman's program is fruitful in the context of an IBL in mathematics.

Keywords: Ábacus; Ausubel and Lipman; Math Teaching.

\section{O ÁBACO NA APRENDIZAGEM POR INVESTIGAÇÃO DE ADIÇÃO E SUBTRAÇÃO}

Este artigo usa a abordagem de Aprendizagem Baseada em Investigação (ABI) como Tecnologia de Ensino no quadro de uma Teoria Educacional que consiste em uma fusão da Teoria da Aprendizagem Significativa de David Ausubel e do Programa de Filosofia para Crianças de Mathew Lipman. O ábaco foi utilizado para ensinar as operações de adição e subtração de maneira significativa. A sequência didática associada foi aplicada a uma escola particular na cidade de Brasília, DF, Brasil, no terceiro ano do ensino fundamental. A aplicação da sequência alcançou seu principal objetivo: fazer a transição de um modelo concreto de duas operações para um modelo bastante abstrato. Concluímos que a sequência didática é válida para demonstrar a eficácia da integração das perspectivas de aprendizagem significativa (Ausubel) e do Programa de Filosofia das Crianças Mathew Lipman por meio da ABI em Matemática.

Palavras-chave: Ábaco; Ausubel e Lipman; Ensino de Matemática.

\section{EL ÁBACO EN EL APRENDIZAJE BASADO EN LA INDAGACIÓN DE LA SUMA Y LA RESTA}

Este documento adopta el Inquire Based Learning (IBL) como una tecnología de enseñanza en el marco de una teoría educativa que consiste en una combinación de la teoría significativa de Ausubel y el programa de filosofía para niños de Mathew Lipman. El ábaco se usó para enseñar sumas y restas de manera significativa. La secuencia didáctica subyacente se aplicó a una escuela privada en la ciudad de Brasilia -FD, a estudiantes de primaria de tercer año. La secuencia didáctica ayudó con éxito a los estudiantes a hacer la transición de un modelo concreto a uno bastante abstracto. Llegamos a la conclusión de que la secuencia didáctica ayuda a demostrar que la integración del aprendizaje significativo (Ausubel) y el programa de Lipman es fructífera en el contexto de un IBL en matemáticas.

Palabras clave: Ábacus; Ausubel y Lipman; Enseñanza de Matemáticas. 


\title{
THE ABACUS IN THE INQUIRE-BASED LEARNING OF ADDITION AND SUBTRACTION
}

\section{Introduction}

When it comes to the primary school I (first to fifth years of the elementary school) it seems that everything is pervaded by fragility. To the fragility of those small bodies there corresponds an even greater fragility of their shinning eyes. For the authors of this paper, working at the university level and accustomed to teach so many times to dull eyes, this fragility is overwhelming.

This puts the issue of teaching those little children, while preserving their eager to know and understand (basically everything), at the highest priority.

Despite being their index of fragility, this eagerness to know and understand is also an important asset in teaching them. They are generally open to learn as no other level in the school, and they present their eagerness by means of sometimes difficult or disconcerting questions for those trying to teach them. In this way, they unravel fragility as the very essence of knowing and teach the teachers back.

These issues give the Inquire-Based Learning Approach (IBLA) a prevailing role as a Teaching Technology for teaching them, for this approach is known to boost the inquiring behavior, instead of making it to fade away, as many memorization-based teaching do.

In this paper we address the teaching of the abilities to add and subtract to third year primary school students using the abacus as the experimental tool. We use IBLA as a Teaching Technology in the framework of an Educational Theory consisting of a merge of David Ausubel's Meaningful Learning Theory and Mathew Lipman's Philosophy for Children Program (SILVA FILHO; FERREIRA, 2018).

This merge of Ausubel's Meaningful Learning Theory (a psychological, largely descriptive, learning theory) and Mathew Lipman's Philosophy for Children Program (an educational prescriptive approach to teaching) was presented elsewhere (SILVA FILHO et al., 2018) and will not be described in this paper. The main articulation of these two approaches will show itself in the use

\author{
plurais


of conceptual maps to prepare the classes, devise the concepts to teach and follow the development and fixation of these concepts in the students' cognitive structures, and the use of Lipman's Investigation Communities to boost interaction within the class and develop the students abilities. Our focus will be directed towards the use of IBLA and its demands.

The use of such a theoretical reference is particularly important in the field of Mathematics. Indeed, much of the mathematical learning, mainly in the elementary school and high school, are of the algorithmic type. One can easily, and wrongly, assume that this sort of learning is naturally connected to mechanic type of learning, that is, memorization. One of the objectives of this paper is to show that this is not necessary, and that the learning of algorithmic behavior in Mathematics alphabetization can be performed in a lively and meaningful way.

\section{Didactic Sequence}

There are some characteristics with which one should comply for the teaching to be considered as an application of the IBLA. One of these characteristics is the statement of one or more problems to be solved by the students. The problems define the investigation to be performed in terms of a set of attitudes that contribute to their solution.

It is also important to adopt an approach that involves, in its beginnings, some sort of manipulation of a number of concrete objects that will lead to the formulation of some concepts. This contributes to an exploration behavior of the students. Indeed, then, planning a didactic sequence that aims at taking the student to construct a certain concept should begin by manipulative activities. In such cases, the question, or problem, should include an experiment, a game or even a text. And passing from the manipulative action to the intellectual construction of the content should be done, now with the help of the teacher, when he takes the student, by means of a series of small questions, to become aware of how the problem is solved and why it was successful, that is, from their own actions (CARVALHO, 2014, p. 03).

In the present application, the concrete object used was the abacus. The final objective is to teach the addition and the subtraction operations in a meaningful way. The use of the abacus comply with the demand that the didactic material should be intriguing to raise the attention of the students, easy to manipulate to make let them manipulate and come to their solutions without 
become too tired. [It also] must allow the student, once he has solved the problem, to diversify his actions, since this is the point at which he can vary his actions and observe correlated variations in the reactions of the object with the objective of giving these regularities some structure (CARVALHO, 2014, p. 11).

The students are assumed to be already aware that numbers consist of places - the place of units, tens and hundreds would be enough to begin with. Thus, to fulfill the final objective, the students have to participate in the solution of a number of chained problems connected with the concepts of number representation and operation with numbers. To a set of problems there corresponds an activity, as shown in what follows.

\section{Activity 1}

The first activity involving all the classroom is the construction of a "human abacus". Three students are called to the front of the class and asked to assume side by side positions. The first student is asked to count continuously and circularly from zero to nine raising the fingers to represent the number being count. The second student is asked to raise her fingers each time the first student arrives at zero. The third student is also asked to raise the fingers each time the second student arrives at zero. The first student begins counting aloud and at some point of the counting (somewhere within the thirties, to avoid the counting to become too monotonous) the teacher asks her to stop counting. Then the teacher asks the classroom which number is being represented by the students at this point. He then asks the first student to resume counting until most of the class can correctly answer to this question. Then the teacher asks the three students to raise their fingers such that they represent together, for instance, the number 94 . The teacher asks the first student to resume counting, such that the third student is now triggered when the counting arrives at 100 . At some point close to 112 the teacher asks again the three students to stop and asks the classroom which number they represent. This can be repeated some times, but not too much, for the counting can become monotonous very quickly. The teacher must stress that no student was made to count a number greater than nine. He then says that this characterizes a decimal representation of a number. At this point of the activity the teacher tells the students that they just have seen a "human abacus" and then shows the abacus made of wood to be used henceforth (see Figure 1).

\section{p/ullais Salvador, v. 5, n. 2, p. 22-39, mai./ago. 2020}


Figure 1 - An open abacus to learn addition and subtraction. In the inset it is presented the closed abacus, that should not be used, since it is more difficult to teach regrouping with it

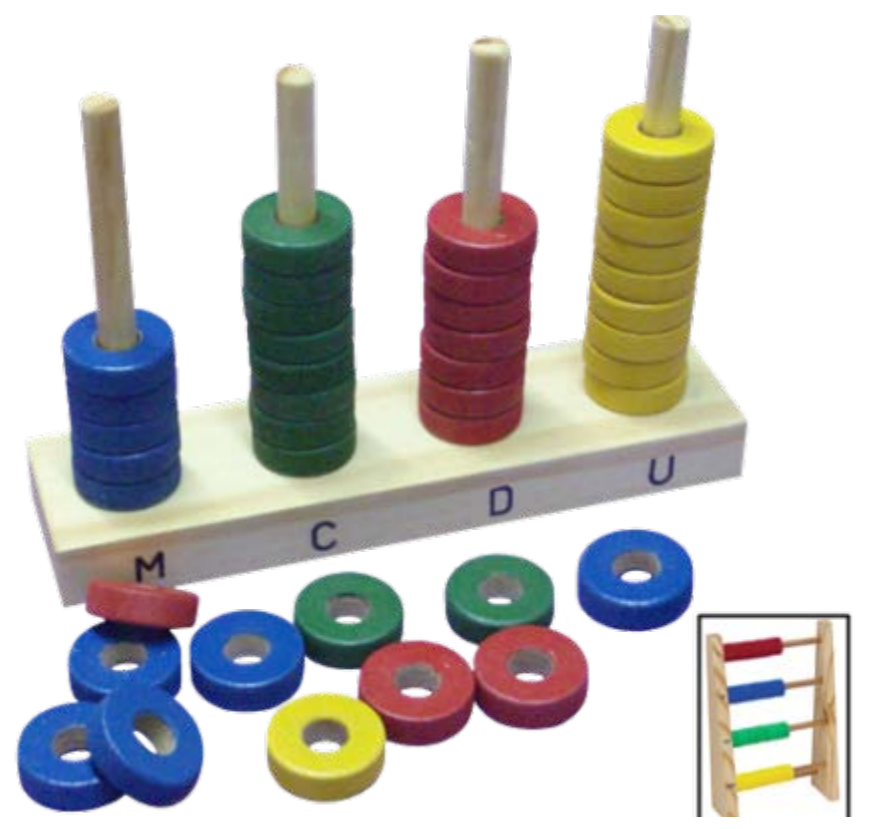

Fonte: Author, 2019.

\section{Activity 2}

In the second common activity the students are first made to quickly explore the abacus to identify numeric places, made concrete by sticks placed vertically side by side, and to associate them with the units, tens and hundreds digits of numbers. The teacher then uses one piece of wood (the small round pieces shown in Figure 1) to place it at each stick alternately, asking after each placing of the piece how much that piece represents. The teacher then holds the piece at his hand and ask again the classroom to tell how much the piece represents (this is one of those marvelous moments that emerges when teaching too young children - most of them simply cannot answer the question and become mesmerized in their seats, while a very small number of students answer that the piece represents nothing unless it is placed on some stick). The round pieces of wood, un- 
fortunately, generally come with different colors, which may induce the student to correlate color and value for the pieces. It is an important that the teacher uses this situation of error to emphasize that all the round pieces are identical and use them interchangeably in the sticks. The teacher can then stress the difference between numbers and digits ("algarismos" in Portuguese), which can be quite fuzzy for many students.

These two activities are made to stress the issue of number representation. At first, only the first three numeric places are mentioned (the place/stick representing the units digit, the one representing the tens digit and the one representing the hundreds digit). They are then asked (first problem) to generalize this representation by saying what the fourth stick in the abacus should represent. To end this activity about representation, the teacher then explains the students the importance of having a decimal representation, by showing that without it, if each new piece represents the successor number, to count up to nine thousands would mean to pile up nine thousand pieces - in a structure bigger than the classroom -, while in the decimal representation it would mean to just use nine pieces of wood (this point generally raises much astonishment). The teacher then asks the students to join into groups (of no more than four or five students) and, after the groups are made, he asks them to represent a small list of numbers, just to make them as much acquainted with the abacus as possible. The teacher must stress that, as with the human abacus, each stick can hold at most ten pieces of wood, like it happened with each student in the "human abacus". These two first activities should take no more than one class of 50 minutes. If the students show easiness to pass these activities, the teacher can then present the notation of numbers using classes and orders, and the use of the comma to make them explicit in number representation. At this stage, students frequently find quite amusing to work with very large numbers, such as $1,323,897,765$ even if only to utter them;

\section{Activity 3}

The next activity introduces number addition. There are a number of details that should be taken into account when teaching this operation. Details at this level of teaching are very important and should not be overlooked by the teacher - moreover, they must be made explicit to the students. The teacher begins asking the students to represent in the abacus some number, for example 143, and then asks them to add this number with the number 2 (no student presents any difficulty to do that). The teacher may ask them to add another number that does not surpass 10 , just for fixation.

\section{plurais


With some number as 147 or 148 , the teacher ask them to add to it the number 231 (such that no stick would have more than ten pieces). It is now very important to ask the students to begin always by the stick representing the units (many students begin by the hundreds because of the way they read: left to right). The teacher should now ask the students to repeat this activity a small number of times (it is assumed that the students already have made such additions in the paper before the application of this didactic sequence). The teacher then asks the students to make some additions both in the abacus and in the paper. This is to stress two important points: firstly the issue of the type of representation (abacus and handwritten), and secondly the process of abstraction, which here represents a partial removal of themselves from the concreteness of the abacus - this should be made explicit to the students, since mathematics is, largely, about such a process.

\section{Activity 4}

The teacher now introduces a new problem by asking the students to represent some number, say 424 , and to add it to the number 36 , for example (or any other number that triggers the regrouping operation - only once at this point). The teacher must stress that this is what defines the decimal representation. This is an activity that should be taken within the groups, with the supervision of the teacher (generally, much astonishment comes at this point, if the students were never presented to regrouping, as we are assuming). This is a somewhat difficult problem for many students and the teacher should follow the groups with greater attention. If one or more groups find the solution, the teacher should use them to explain to the whole class what they have done, while asking them the reasons underpinning their strategy. This is important to comply with teaching the ability of expressing problems and their solutions in the students' own terms and also the reasoning ability. If any group finds the solution, the teacher can give some hints, using a different addition of two numbers less than ten (say 4 and 8 ). At this point, the teacher should show in his own abacus that ten pieces in the stick of the units digit are equal to one piece in the stick of the tens digit, while ten pieces in the stick of the tens are equal to one piece in the stick of the hundreds and that $t o$ keep each stick with less than ten pieces it is necessary to regroup ten of them and pass them to the next stick. He may call about the generalization of this reasoning at this point to a fourth stick, the thousands digit, that generally comes with the abacus.

The students are then asked to resume trying to solve the problem they were given (this stresses the importance of the teacher in the construction of the knowledge, while specifying some 
boundaries of its role). There are some generalization behavior involved in the activity, since they must assume that the same regrouping ought to apply to the other sticks (or decimal places).

\section{Activity 5}

After the completion of the previous activity, the students are now asked to perform the same task of adding using the abacus. Now, however, they must make the calculations both using the abacus and the paper. This process makes a smooth transition between the concrete material abacus, and the more abstract handwritten calculation. Activities 3 through 5 should take a class during 50 minutes or, maybe, two classes of 50 minutes.

\section{Activity 6}

This activity and the next one should be made to occupy one entire class of 50 minutes. Now the students, by themselves and with the supervision of the teacher, keeping their groups already defined in a previous class, should: (a) find an algorithm to make subtraction using a list of pairs of numbers. The list is constructed in such a way that, initially, they may perform the subtractions without the need of regrouping. Then, (b) they are asked to perform subtractions that will need regrouping and they are expected to devise a way to subtract a larger number from an smaller one. This involves a quite large amount of abstraction, since they do not know negative numbers yet. Finally, they should make a list of subtractions, with and without regrouping, only on a sheet of paper.

\section{Activity 7}

In this last activity, the teacher should ask the groups (not the students individually) to use their abacuses to represent very large numbers (such as numbers with seven or eight digits - considering that each abacus has four sticks). This is an interesting problem, because the students will have to find out, cooperatively, that it is necessary to combine their abacuses to be able to represent larger numbers. After this initial activity is performed, the teacher should present abacuses' limitations due to its material structure, by arguing that very large numbers will make it necessary the use of countless abacuses, making the process quite cumbersome, if not impossible. The teacher should stress the importance of having a paper to represent numbers by just writing them out. Then, a last activity may be performed using only paper and pencils to fix the abstraction process.

\section{plurais}


This didactic sequence can be summarized in terms of the problems it proposes as shown in Table 1.

Table 1 - Didactic sequence showing the problem(s) involved in each activity and the time duration of each class.

\begin{tabular}{|c|c|c|}
\hline Activity & Problem(s) & Duration (mins) \\
\hline 1 & (a) make human abacus; (b) comparison with true abacus & \multirow[b]{2}{*}{$2 * 50$} \\
\hline 2 & $\begin{array}{l}\text { (b) representation of numbers using the abacus; (c) representation } \\
\text { of numbers using pencil and paper }\end{array}$ & \\
\hline 3 & (a) addition of numbers without regrouping & \multirow{3}{*}{$3 * 50$} \\
\hline 4 & (b) addition of numbers with regrouping using the abacus & \\
\hline 5 & $\begin{array}{l}\text { (c) addition of numbers with and without regrouping using the } \\
\text { abacus and pencil and paper }\end{array}$ & \\
\hline 6 & $\begin{array}{l}\text { (a) subtract numbers without regrouping (b) subtract numbers } \\
\text { with regrouping }\end{array}$ & \multirow{2}{*}{$2 * 50$} \\
\hline 7 & $\begin{array}{l}\text { (a) representation of large numbers using the abacuses of the } \\
\text { group }\end{array}$ & \\
\hline
\end{tabular}

Fonte: Author, (2019).

After the application of this didactic sequence, the next activities are those necessary to fix the operations of addition and subtraction, usual to any mathematical learning.

The previous didactic sequence is intended to give the reasons underlying the operations of addition and subtraction, while helping the students do develop a Thinking of Superior Order (LIPMAN, 1995, part II). Indeed, it involves the development of

- Critical thinking in the sense that the students learn (and are called to utter these reasons during the discussions);

- Cautious thinking in the sense that much care is taken to present the aforementioned reasons in detail, with the abacus as a material model;

- Creative thinking in the sense that they are asked to make some generalizations and the translation of the regrouping to perform addition into the one related to perform subtraction. 
This Thinking of Superior Order is related to the development of abilities in the cognitive structure of the students, such as those of (SILVA FILHO; FERREIRA, 2018)

1. Reasoning: when the students are asked to give the reasons for the regrouping methods, when they are asked to compare the use of the abacus and pencil and paper, and other situations that appear in the classes;

2. Concept formation: regrouping, representation, base ten representation, and some other concepts that are made explicit in the next section;

3. Investigation: by the very method to get the knowledge related to the two operations;

4. Translation: by being asked to express, using their own words, the reasons of regrouping and other issues that appear in all three classes.

Thus, it is important that the teacher organizes the inquire-based approach of each class introducing some of these elements in the discussions. Furthermore, all the groups should always convene in discussions that are capable of revealing the acquisition and development of the aforementioned abilities, thus turning the class into a Community of Investigation.

It seems immediate to conclude that the type of learning here proposed fits quite well into what Ausubel defines as meaningful learning. There is no mechanical learning, despite there is a learning of algorithmic thinking. The previous knowledge already present in the cognitive structure of the students (their subsumers) is also taken into account and the first activity is meant as a previous organizer of these subsumers.

\title{
Concepts to teach and their conceptual map
}

There are a number of concepts that naturally appear in the course of the classes. They are presented in this section as a conceptual map, as shown in Figure 2.

One thus can read this map by saying that:

- Numbers are represented by places. These places are the sticks in the abacus. Both places and sticks represent digits (no definite notation yet). Thus, in the base ten notation, sticks

\author{
plurais


may represent units digit, tens digit or hundreds digit, depending on their being at the first, second or third position, respectively. This arrangement is endless, meaning that numbers are infinite. The fact that one has sticks representing units digit, tens digit, hundreds digit, etc mean that we are within a base ten notation, which is a choice of ours.

- Numbers can be operated with each other. There are (at this point) two operations. Addition and subtraction.

- Addition can happen with or without the need of regrouping. Regrouping is necessary when the digit (number of round wood pieces) at some place (or stick) becomes greater than 10 . If not, regrouping is not necessary.

- Subtraction can happen with or without the need of regrouping. Regrouping is necessary when the digit (resulting number of round wood pieces) at some place (or stick) would become less than zero. If not, regrouping is not necessary.

Figura 2 - The main concepts that the students should have to learn addition and subtraction by the abacus.

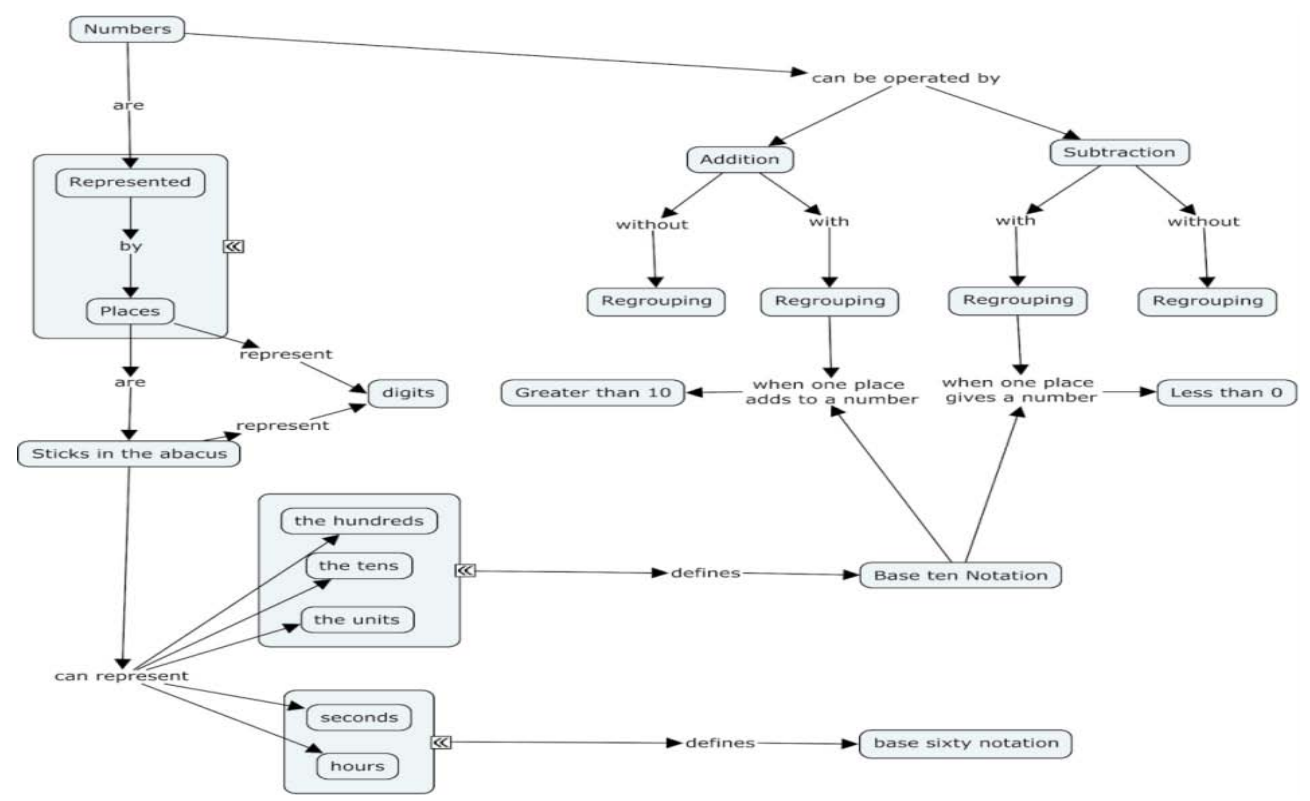

Fonte: Author, 2019. 
These are the main concepts that the students should learn. It is possible to the teacher to use the conceptual map as a tool to improve the students' understanding of the topic by constructing it together with the class.

Normally, at the third series of primary school, the students should learn also the representation of time. It would be interesting that the teacher, when beginning to teach time representation, resumes the explanations using the same reasoning. In this way, he will be teaching a much deeper mathematical topic: representation of numbers in different bases, which might contribute to the development of the ability of abstraction. Learning base two representation using the abacus may be full of amusement and is recommended if time allows its application (it can also be connected to how computers work, giving the students a glimpse of the importance of number representation).

\section{Applications and Results}

This didactic sequence was applied to a private school in the city of Brasilia, D.F., Brazil Colégio Marista Asa Sul. It was applied by one of the authors (hereafter the experimenter) to third year primary school classes with approximately 30 students per class. The students are generally between 8 and 9 years old (see Figure 3).

Figure 3 - The experimenter in one of the classes.

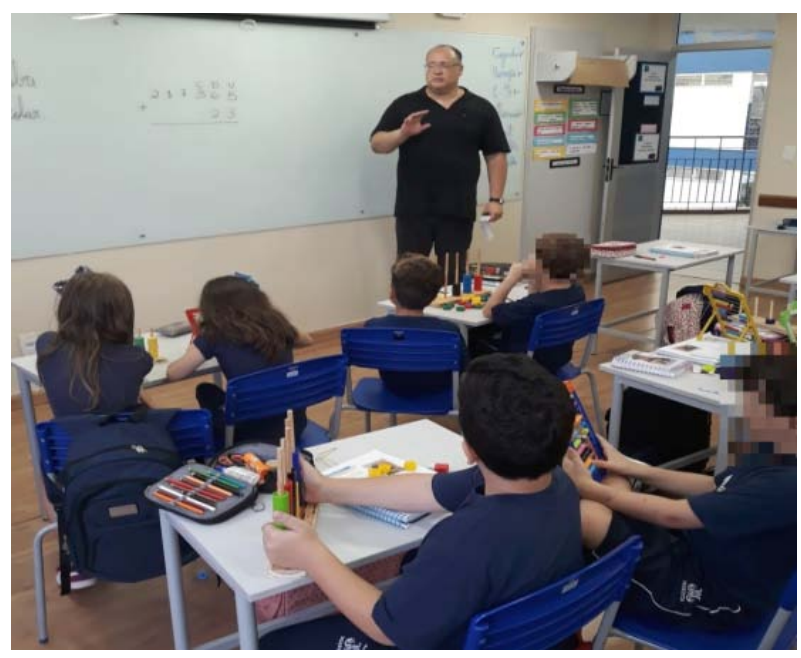

Fonte: Author, 2019. 
The topic had to be presented to all nine classes (A to I) of the school (five in the morning period, four in the afternoon period). Each class was 50 minutes long. In all theses classes, the school's original teacher of the class helped the experimenter in the process of application. In two classes, there was the school original teacher, responsible for the class, and one assistant. In two other classes there were the teacher and two other assistants, because they had students with some peculiarity - in one of them, there was a blind student, in the other there was a student presenting what seemed to be a behavior within the autistic spectrum. In all other classes (5) there was only the school original teacher to help the experimenter.

Instead of the three classes of 50 minutes proposed in this didactic sequence, it has to be applied in only one class of 50 minutes. This fact lead the teacher applying this didactic sequence to focus on one or two of the activities proposed in Table 1, instead of all of them, for each class.

Thus, the horizontal character of the didactic sequence (the fact that it was thought to be applied in three lessons of 50 minutes for the same class) was substituted by a vertical character (the fact that it had to be applied in one 50 minutes lesson to nine different classes). Despite the fact that this was much farther than the ideal, this vertical character, together with its underlying heterogeneity, brought some interesting elements that implied in some richness for the application.

The first heterogeneity observed was the different stages at which each class was. Class A, for instance, had already seen addition and subtraction, but both without regrouping. However, the students were never presented to the abacus before. This made the application of the first two activities and the last one (those related to the representation of numbers using the abacus) quite adequate. The class was previously divided in six groups of four (24 students in the class) and the problem of representing large numbers caused quite a frenzy (see Figure 4). One group found the answer and one of its members was asked to tell the class what the solution was in his own words. 
Figure 4 - Solving one of the activities.

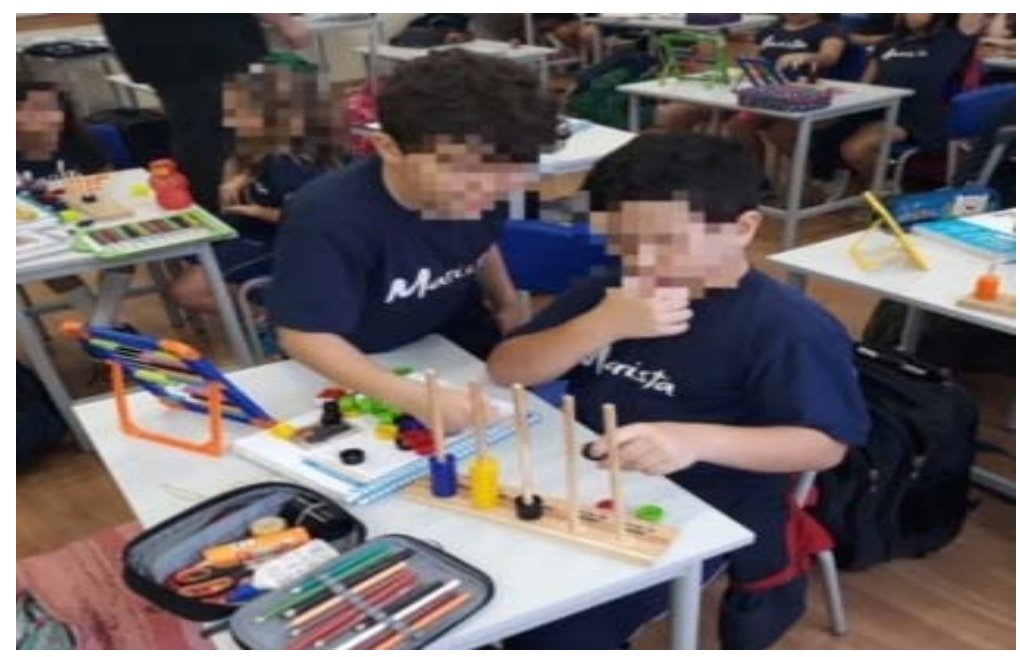

Fonte: Author, 2019.

It was observed by the experimenter that in class A some groups got lost in the process and quickly stop paying attention to the activity. This was closely related to the control of a fruitful behavior in a class interested in inquire-based learning. The same problem appeared again in one other class (in which the teacher had just become the one responsible for the class and was as strange to the class as the experimenter). In all other classes, the control of the teacher over the class behavior was very strict and it was observed that the application of the didactic sequence affected the students more profitably and with more homogeneity. Indeed, disciplinary actions are connected to the execution of the activities, but are grounded on interpersonal relationships. To ask the students for attention to a certain discussion, to inform each activity that will be done and reprehend inadequate behaviors of students are part of the disciplinary actions of the class (SASSERON, 2014).

In some classes, the students were already presented to the abacus, they had already seen its representation function (despite not in the same terms as assumed in the present didactic sequence), but had not been used to represent the two operations, addition and subtraction. In these classes, it was possible to apply activities 3 to 7 , although with less details and reinforcement than

\footnotetext{
plupais 
it would be the ideal - the comparison with the pencil and paper calculations had to be made by the experimenter in the whiteboard of the class. It was observed by the experimenter that many students quickly developed very good skills in both operations, and performed quite well in the activity in which they would have to develop subtraction with regrouping based on what they had learned about addition.

Another important difference among classes was the fact that not all teachers were prepared for the application of the didactic sequence and the requisite of group formation was not strictly followed in some classes (see Figure 5). Maybe this happened because there was no previous encounter between the experimenter and all the teachers. The application of the didactic sequence was explained to many of them by the teacher that was in direct contact with the experimenter and the somewhat important element of group formation certainly escaped some of them. Since the experimenter was able to turn all classes in an Investigation Community, with many students actively participating in the activity, this problem of group formation was not relevant to the results of the application.

Figure 5 - A situation in which there was no group formation.

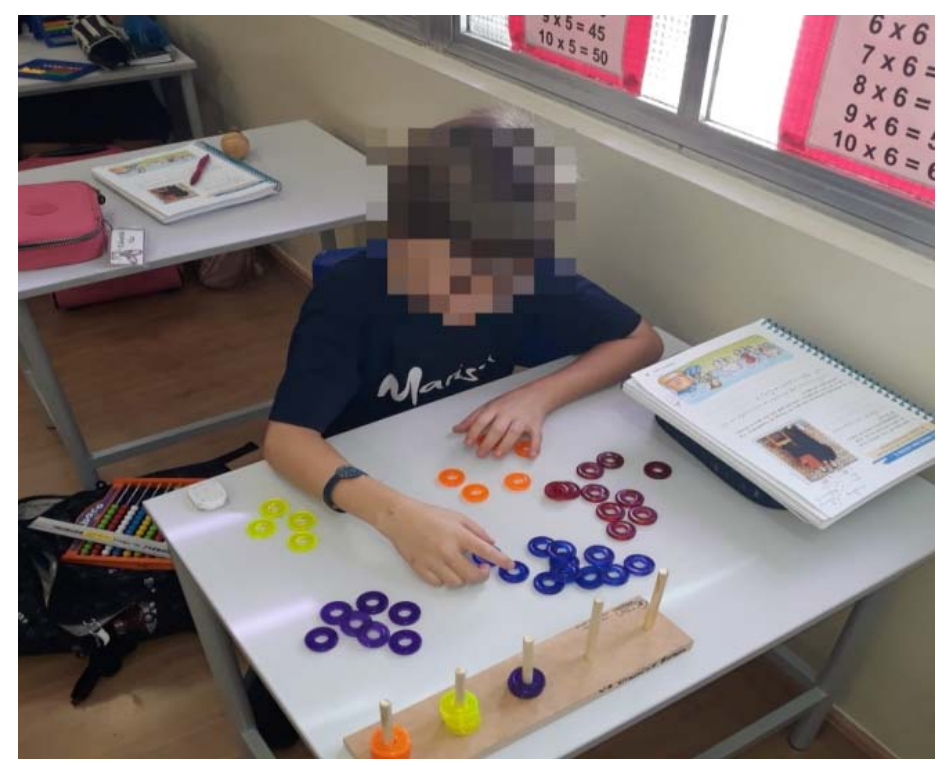

Fonte: Author, 2019. 
It became clear to the experimenter that the application of the sequence was quite successful in its main objectives. These objectives were: making the transition from a concrete model for the two operations to a rather abstract model, getting the students to construct their own reasoning about many issues regarding numbers and decimal notation, getting them to express what was going on using their own words and develop good skills in applying the addition and subtraction algorithms. It was seen that the transition to the regrouping algorithms was quite smooth and without problems to almost all the students.

As an anecdotal evidence of the adequacy of the didactic sequence, in one class, one of the assistants uttered to the experimenter her own testimony that she had been presented to the abacus before, but it was at the application of this didactic sequence, in a class that she was assisting, that showed her how the abacus should be concretely used to understand the operations of addition and subtraction. This gives some expectation that the same methodology should be used with older students, which have not acquired mathematical alphabetization when they were young, and now are students in classes specifically projected to them (the teaching of young and adults that lost largely their age-class correspondence).

\section{Conclusion}

This article discusses the application of a didactic sequence based on Inquiry Based Learning in Mathematics. For this, it was used the Abacus to teach addition and subtraction to third graders and to show that mathematics learning can take place significantly rather than traditional methods of memorization.

During the application, some elements emerged and should be recorded in the proposed methodology: the class heterogeneity regarding mathematical knowledge and use of abacus, the importance of teacher-student relationship, the development of skills through the research community, and, the preparation of teachers for the application of the didactic sequence.

Finally, we conclude that the application has achieved its main objectives, from the transition from a concrete model concerning both operations to a very abstract model to the construction of the solution to the proposed problem. Thus, the didactic sequence is valid for demonstrating the effectiveness of integrating meaningful learning perspectives (Ausubel) and Mathew Lipman's

\section{plurais


Philosophy for Children Program through the Inquiry-Based Learning Approach (IBLA) in Mathematics.

\section{REFERENCES}

LIPMAN, M. O pensar na educação. 2. ed. Translated by Ann Mary Fighiera Perpétuo. Petrópolis: Vozes, 1995.

SILVA FILHO, O.; FERREIRA, M. Teorias da Aprendizagem e da Educação como Referenciais em Práticas de Ensino: Ausubel e Lipman. Revista do Professor de Física, v. 2, n. 2, p. 104$125,2018$.

CARVALHO, A. M. P. O ensino de ciências e a proposição de sequências de ensino investigativas. In: Carvalho, A.M.P. (Org). Ensino de Ciências por Investigação. São Paulo: Cengage, 2014.

SASSERON, L. H. Interações Discursivas e Investigação em Sala de Aula: O Papel do Professor. In: Carvalho, A.M.P. (Org). Ensino de Ciências por Investigação. São Paulo: Cengage, 2014.

Recebido em: 03 de junho de 2020.

Inserido em: 10 de agosto de 2020.

Esta obra está licenciada com uma Licença Creative Commons Atribuição 4.0 Internacional. 